\title{
Nitrogen balance and fate in a heavily impacted watershed (Oglio River, Northern Italy): in quest of the missing sources and sinks
}

\author{
M. Bartoli ${ }^{1}$, E. Racchetti ${ }^{1}$, C. A. Delconte ${ }^{2}$, E. Sacchi ${ }^{2}$, E. Soana ${ }^{1}$, A. Laini ${ }^{1}$, D. Longhi ${ }^{1}$, and P. Viaroli $^{1}$ \\ ${ }^{1}$ Department of Environmental Sciences, University of Parma, Viale G.P. Usberti 33/A, 43124 Parma, Italy \\ ${ }^{2}$ CNR-IGG, U.O.S. Pavia and Department of Earth and Environmental Sciences, University of Pavia, via Ferrata 1, \\ 27100 Pavia, Italy
}

Correspondence to: M. Bartoli (marco.bartoli@unipr.it)

Received: 17 July 2011 - Published in Biogeosciences Discuss.: 12 September 2011

Revised: 7 December 2011 - Accepted: 18 December 2011 - Published: 18 January 2012

\begin{abstract}
We present data from a comprehensive investigation carried out from 2007 to 2010, focussing on nitrogen pollution in the Oglio River basin $\left(3800 \mathrm{~km}^{2}\right.$, Po Plain, Northern Italy). Nitrogen mass balances, computed for the whole basin with 2000 and 2008 data, suggest a large $\mathrm{N}$ surplus in this area, over $40000 \mathrm{t} \mathrm{N} \mathrm{yr}^{-1}$, and increasing between 2000 and 2008. Calculations indicate a very large impact of animal husbandry and agricultural activities in this watershed, with livestock manure and synthetic fertilizers contributing $85 \%$ of total $\mathrm{N}$ inputs (about $100000 \mathrm{t} \mathrm{N} \mathrm{yr}^{-1}$ ) and largely exceeding crop uptake and other $\mathrm{N}$ losses (about $60000 \mathrm{t} \mathrm{N} \mathrm{yr}^{-1}$ ). Nitrogen from domestic and industrial origin is estimated as about 5800 and $7200 \mathrm{t} \mathrm{N} \mathrm{yr}^{-1}$, respectively, although these loads are overestimated, as denitrification in treatment plants is not considered; nonetheless, they represent a minor term of the $\mathrm{N}$ budget. Annual export of nitrogen from the basin, calculated from flow data and water chemistry at the mouth of the Oglio River, is estimated at $13000 \mathrm{t} \mathrm{Nyr}^{-1}$, and represents a relatively small fraction of $\mathrm{N}$ inputs and surplus $(\sim 12 \%$ and $34 \%$, respectively). After considering $\mathrm{N}$ sinks in crop uptake, soil denitrification and volatilization, a large excess remains unaccounted $\left(\sim 26000 \mathrm{t} \mathrm{N} \mathrm{yr}^{-1}\right)$ in unknown temporary or permanent $\mathrm{N}$ sinks. Nitrogen removal via denitrification was evaluated in the Oglio riverbed with stable isotope techniques $\left(\delta^{15} \mathrm{~N}\right.$ and $\delta^{18} \mathrm{O}$ in nitrate). The downstream final segment of the river displays an enriched nitrate stable isotope composition but calculations suggest a $\mathrm{N}$ removal corresponding to at most $20 \%$ of the unaccounted for $\mathrm{N}$ amount. Denitrification was also evaluated in riverine wetlands with the isotope pairing technique. Areal rates are elevated but overall $\mathrm{N}$ removal is low (about $1 \%$ of the missing $\mathrm{N}$ amount), due to small wetland surfaces and limited lateral connectivity. The secondary drainage channel network has a much
\end{abstract}

higher potential for nitrogen removal via denitrification, due to its great linear development, estimated in over $12500 \mathrm{~km}$, and its capillary distribution in the watershed. In particular, we estimated a maximum $\mathrm{N}$ loss up to $8500 \mathrm{t} \mathrm{Nyr}^{-1}$, which represents up to $33 \%$ of the unaccounted for $\mathrm{N}$ amount in the basin. Overall, denitrification in surface aquatic habitats within this basin can be responsible for the permanent removal of about $12000 \mathrm{t} \mathrm{N} \mathrm{yr}^{-1}$; but the fate of some $14000 \mathrm{t}$ remains unknown. Available data on nitrate concentration in wells suggest that in the central part of the watershed groundwater accumulates nitrogen. Simultaneously, we provide evidences that part of the stored nitrate can be substantially recycled via springs and can pollute surface waters via rivergroundwater interactions. This probably explains the ten fold increase of nitrate concentration in a reach of the Oglio River where no point pollutions sources are present.

\section{Introduction}

Over the last $50 \mathrm{yr}$, nitrogen cycling in watersheds heavily exploited by urbanization, agriculture and animal farming has undergone major alterations as a consequence of multiple interplaying factors (Vitousek et al., 1997). Sewage treatment plants, manure production and spreading, use of industrially fixed nitrogen fertilizers, fixation by crops and atmospheric deposition have resulted in point and diffuse releases of reactive nitrogen into the environment greatly exceeding crop uptake and other N-removal processes in soil and aquatic compartments (Puckett, 1995; Cassman et al., 2002; Galloway et al., 2008). Simultaneously, intensive agricultural practices have simplified the landscape and removed natural buffers as vegetated riparian areas and wetlands. The absence of these elements has greatly enhanced 
nitrogen lateral and vertical migration and made the surface and groundwater more prone to nitrogen contamination (Balestrini et al., 2011). This risk is augmented by the use of large water volumes for irrigation and by traditional practices based on soil flooding over permeable areas, that enhance $\mathrm{N}$ loss via runoff and leaching (Cassman et al., 2002; Böhlke et al., 2007). High infiltration rates decrease groundwater residence time, altering rates of biogeochemical reactions; elevated concentrations of nitrogen in surface waters saturate microbial processes and uptake by primary producers, making nitrogen control by natural processes less effective (Böhlke et al., 2007; Mulholland et al., 2008). This increased $\mathrm{N}$ loading has a suite of negative consequences, including demonstrated health effects, enhanced eutrophication, and contributions to global warming (Ward et al., 2005; Davidson, 2009). Open questions about the fate of the nitrogen surplus in impacted watersheds concern where and for how long does the excess nitrogen accumulate, and what processes and transformations does it undergo (van Breemen et al., 2002; Puckett et al., 2011).

We addressed these and related questions in the lower Oglio River, a central sub-basin $\left(3800 \mathrm{~km}^{2}\right)$ of the Po River watershed, which is the largest river basin in Italy $\left(71057 \mathrm{~km}^{2}\right)$. About $50 \%$ of the Po watershed is exploited for agriculture. The Po basin hosts a human population of over $17 \times 10^{6}$ inhabitants, approximately $3.1 \times 10^{6}$ cattle ( $\sim 50 \%$ of the national stock) and $6.0 \times 10^{6}$ pigs ( $\sim 65 \%$ of the national stock). Agriculture and livestock together contribute to $\sim 80 \%$ of the total nitrogen load generated by the Po River basin $\left(\sim 550000 \mathrm{t} \mathrm{N} \mathrm{yr}^{-1}\right)$, which has led to a diffuse nitrate contamination of both surface and groundwater (Cinnirella et al., 2005). Furthermore, the annual nitrate load exported from the Po River basin has increased 2-3-fold over two decades, from $\sim 40 \times 10^{6} \mathrm{t} \mathrm{N} \mathrm{yr}^{-1}$ in the period $1968-1972$ to $80 \times 10^{6} \mathrm{t} \mathrm{Nyr}^{-1}$ (dry years) up to $143 \times 10^{6} \mathrm{t} \mathrm{N} \mathrm{yr}^{-1}$ from 1990 onwards. This delivery of $\mathrm{N}$ represents the major N input term in the Adriatic Sea (Franco and Michelato, 1992; Zoppini et al., 1995).

Within the Po River watershed, we analyzed the sub-basin of the lower Oglio River, due to its elevated human population and farmed animal densities, maize-oriented intensive agriculture, highly permeable soils, landscape simplification and flood irrigation practices. Original data and information from multiple recent studies are here presented with the goal of quantifying the $\mathrm{N}$ sources, sinks, and major transformations within this watershed. First we provide background on the patterns of nitrate concentrations along the river course, followed by a summary of the major input and output terms in the $\mathrm{N}$ budget, including an estimate of $\mathrm{N}$ exported via river discharge and $\mathrm{N}$ removed via denitrification in surface water compartments within the basin. Finally, we evaluate the role of groundwater as $\mathrm{N}$ sink and that of springs as hotspots of $\mathrm{N}$ recycling.

\section{Study area}

All the data and calculations presented in this work refer to the lower Oglio River, a $156 \mathrm{~km}$ long watercourse (from here onwards Oglio River), and its watershed, comprising a total surface of $3800 \mathrm{~km}^{2}$. The Oglio River originates from a subalpine lake, Lake Iseo and flows into the Po River (Fig. 1). According to the Köppen classification the study area has an humid subtropical climate, with a mean annual temperature of $\sim 13^{\circ} \mathrm{C}$ and an annual precipitation of $\sim 800 \mathrm{~mm}$. The Oglio River regulation practices optimize the amount of water that flows through a series of 6 hydroelectric power plants located within the first $22 \mathrm{~km}$ of the reach. They maintain lake water level within a narrow range ( 184.85 to $186.55 \mathrm{~m}$ a.s.l.) and retain lake water during non-irrigation periods in order to release more water for agricultural needs during summer. Water release from Lake Iseo is $45 \pm 33 \mathrm{~m}^{3} \mathrm{~s}^{-1}$ during the non-irrigation period and $67 \pm 32 \mathrm{~m}^{3} \mathrm{~s}^{-1}$ (www.laghi.net/Oglio/) during the irrigation period, generally between May and September. During the irrigation period up to $85 \mathrm{~m}^{3} \mathrm{~s}^{-1}$ can be diverted into a series of artificial channels, mostly located along the Oglio's initial $42 \mathrm{~km}$. As a consequence, water flow in the Oglio River is generally at its minimum immediately downstream of these diversions.

Arable land represents about $60 \%$ of the total Oglio River watershed area and maize is the dominant crop covering about $65 \%$ of the arable surface (Agricultural Information System of Lombardy Region, 2008; www.siarl.regione. lombardia.it). In more than two thirds of the arable land, irrigation is performed via submersion, a traditional practice made possible by both abundant water availability in this area and by coarse-textured soils. The Oglio River crosses the Po Plain, the largest alluvial basin in Italy, derived mostly from erosion of the Alps during the Quaternary. Soil particle size decreases with increasing distance from the sediment source, from northwest to southeast across the Oglio watershed (Brenna et al., 2004). Accordingly, the permeability of the unconfined aquifer in the gravels and sands of the higher plain greatly exceeds that of the more clay-rich lower plain. The water table depth varies from about $30 \mathrm{~m}$ in the northwest to $2-3 \mathrm{~m}$ in the southeast (Carcano and Piccin, 2002). The transition between the two areas is marked by numerous permanent outflows, the so-called "springs belt", that runs parallel to the Alps and is crossed by the Oglio River approximately $30 \mathrm{~km}$ south of the Lake Iseo. The Oglio River is fed by groundwater along most of its length (Lombardy Region, 2006).

\section{The nitrate "anomaly" in the Oglio River}

From 2007 to 2010 we conducted detailed, seasonal-based monitoring of the Oglio River water, in the framework of a project aimed at defining restoration strategies and the 

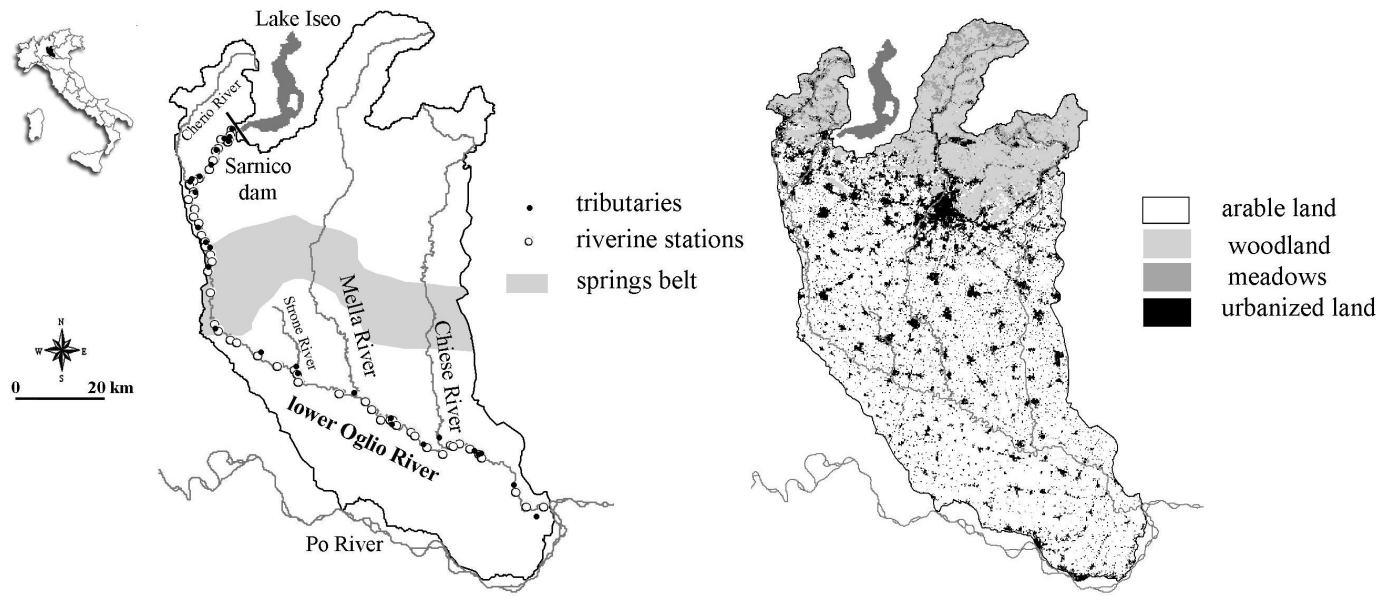

Fig. 1. The map on the left shows the lower Oglio River, its main tributaries, the area within the basin where springs are located and the sampling stations; the map on the right reports the land use within the basin. With lower Oglio River and lower Oglio basin we indicate the river segment that originates from the Lake Iseo and flows into the Po River and its associated watershed.

minimum vital flow of this river (Racchetti et al., 2008, 2010). Water samples were collected from 80 stations along the river course, including riverine sites $(n=60)$, tributaries $(n=14)$, and point sources such as wastewater treatment plants (WWTPs, $n=6$, Fig. 1). All samples were analyzed for dissolved and particulate nitrogen forms $\left(\mathrm{NH}_{4}^{+}, \mathrm{NO}_{2}^{-}\right.$, $\mathrm{NO}_{3}^{-}$, dissolved organic -DON- and particulate -PN-) by means of standard spectrophotometric techniques (A.P.H.A., 1981). Flow measurements were performed by Oglio Consortium, the Oglio River water management authority.

This monitoring data revealed recurrent nitrate trends during summer campaigns over the 4-yr period. In particular, nitrate concentrations displayed a steep, 10 -fold increase from about 0.8 to $7.7 \mathrm{mg} \mathrm{N}^{-1}$ over the relatively short reach between $\mathrm{km} 25$ to $\mathrm{km} 50$ (Fig. 2). This reach contains the section of the Oglio River downstream from the last great diversion for irrigation, and is the portion characterized by low flows (5 to $10 \mathrm{~m}^{3} \mathrm{~s}^{-1}$ ). We calculated from flow and concentration data that the $\mathrm{N}^{-\mathrm{NO}_{3}^{-}}$increase is equivalent to an

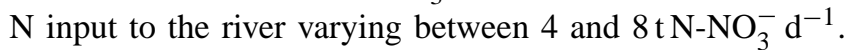
However, this reach contains no significant tributaries nor WWTPs, which means that point sources are not responsible for the nitrate load. Ammonium and organic nitrogen concentrations are generally low $\left(<0.14 \mathrm{mg} \mathrm{N}^{-1}\right)$, so coupled ammonification and nitrification cannot be responsible for the measured nitrate increase. We thus hypothesized a generalized problem of diffuse nitrate contamination in this area. To verify this hypothesis we conducted a catchment scale $\mathrm{N}$ inventory, including all the potential $\mathrm{N}$ sources and sinks.

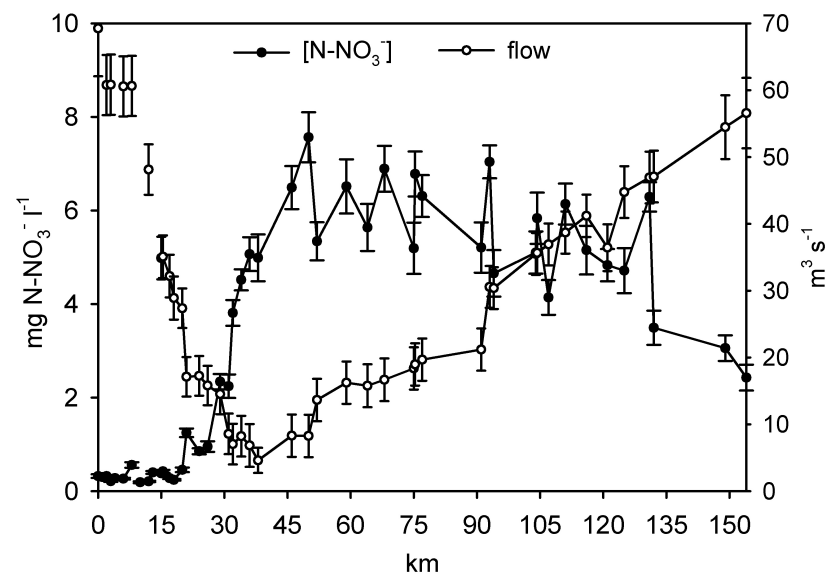

Fig. 2. Concentration of nitric nitrogen and water flow in the Oglio River during summer season. Values are averages ( \pm standard deviation) from whole river samplings carried out on 3-5 July 2007 , 9-11 July 2008, 5-7 August 2009 and 28-30 July 2010.

\section{Nitrogen mass balance in the Oglio River watershed}

\subsection{The contribution of agriculture and animal farming}

A detailed nitrogen mass balance was conducted according to the soil system budget approach (Oenema et al., 2003). This work had a twofold aim: (1) verify whether uncoupled input and output terms generate a large $\mathrm{N}$ surplus in this basin and (2) identify those areas within the watershed where the risk for surface and groundwater pollution is highest. The soil system budget was calculated on an annual basis (for the years 2000 and 2008) as the net difference between $\mathrm{N}$ inputs (livestock manure, synthetic fertilizers, atmospheric 
deposition, biological fixation and wastewater sludge) and $\mathrm{N}$ outputs (crop uptake, ammonia volatilization and denitrification in soils) within the catchment's agricultural land. $\mathrm{N}$ budget calculations were performed at a spatial resolution of individual municipalities (over 250, having a surface from 500 to 9000 ha) using farming census data (National Statistics Institution, 5th Agricultural Census 2000; http://censagr.istat. it/dati.htm; Agricultural Information System of Lombardy Region, 2008; www.siarl.regione.lombardia.it), then aggregated to the catchment scale by means of GIS techniques. The overall budget gains robustness from the comprehensive and high-resolution datasets available for this area and the use of site-specific agronomic coefficients (for more details see Soana et al., 2011). Uncertainties derive from those rates (i.e. ammonia volatilization and denitrification in soils) taken from the literature (Bussink et al., 1998; Asman et al., 1998; Rotz et al., 2004; Smil, 1999) as no data are available for the investigated area. An interval of confidence was associated to the input, output and surplus terms of the 2008 budget by using minimum and maximum parameters for each specific item (Soana et al., 2011). Calculations indicated that in 2000 total $\mathrm{N}$ input was about $80000 \mathrm{t} \mathrm{yr}^{-1}$ and that most of such input was due to manure $(50 \%)$ and to synthetic fertilizers (35\%). Output terms accounted for about $50000 \mathrm{t} \mathrm{N} \mathrm{yr}^{-1}$ and were mostly sustained by crop uptake $(65 \%)$. The difference between inputs and outputs indicates an excess of about $30000 \mathrm{t} \mathrm{N} \mathrm{yr}^{-1}$. The $\mathrm{N}$ budget estimated for the year 2008 was also positive, with inputs exceeding outputs by about $40000 \mathrm{t} \mathrm{N} \mathrm{yr}^{-1}$. $\mathrm{N}$ inputs from livestock manure and synthetic fertilizers increased by approximately $20 \%$ in an almost $10 \mathrm{yr}$ period. For both years, and almost everywhere in the catchment, livestock manure was the biggest $\mathrm{N}$ source (Table 1); the only exceptions were some mountain municipalities with less intensive animal farming.

The comparison between $\mathrm{N}$ input and output suggests an elevated $\mathrm{N}$ surplus in this watershed, averaging $180 \mathrm{~kg} \mathrm{Nha}^{-1}$ arable land (AL) $\mathrm{yr}^{-1}$ in 2008 . The $\mathrm{N}$ surplus varies greatly across the basin (Fig. 3). The most critical zone is the central portion of the Oglio River watershed, where some municipalities have a $\mathrm{N}$ surplus exceeding $400 \mathrm{~kg} \mathrm{~N} \mathrm{ha}^{-1} \mathrm{AL} \mathrm{yr}^{-1}$. To put this surplus in context, the total $\mathrm{N}$ amount (not $\mathrm{N}$ surplus) recommended by the European Community to be spread on arable lands via manure varies between 170 and $340 \mathrm{~kg} \mathrm{~N}^{-1} \mathrm{AL} \mathrm{yr}^{-1}$ (Nitrates Directive, 91/976/EEC) in vulnerable and non vulnerable zones, respectively. The comparison of the $\mathrm{N}$ mass balance between the two years suggests that the critical situation of the year 2000 did not improve, on the contrary we calculated an even larger $\mathrm{N}$ surplus in 2008. This contradicts the indications of the Nitrates Directive specifically aiming at the reduction of $\mathrm{NO}_{3}^{-}$pollution in surface and groundwater of Nitrate Vulnerable Zones.

The Nitrogen Use Efficiency (NUE) of agroecosystems is defined as the proportion of all $\mathrm{N}$ inputs that is removed via the harvest of aboveground material in crops (Liu et al.,

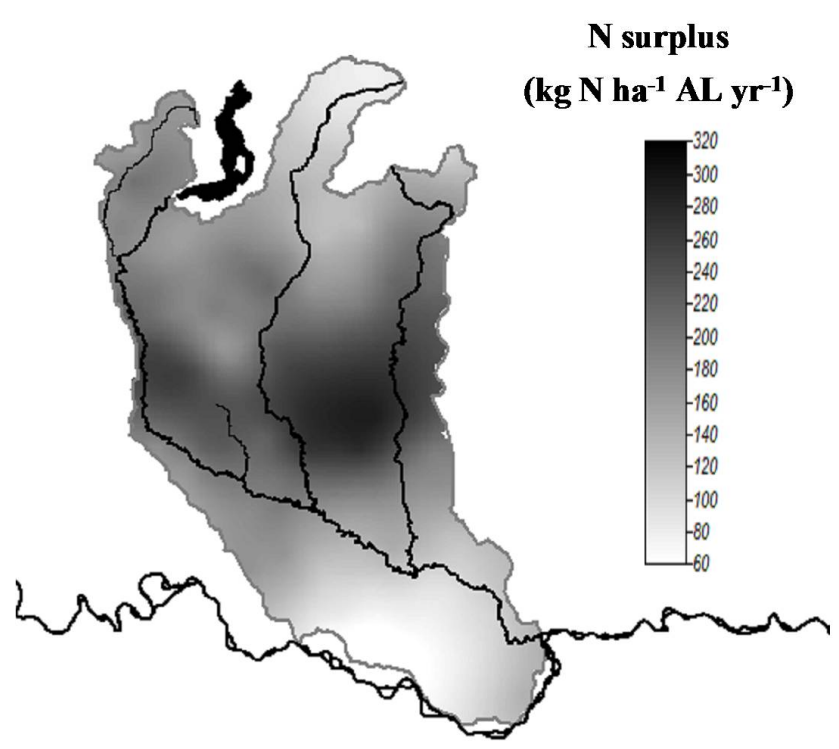

Fig. 3. Spatial distribution of $\mathrm{N}$ surplus (=difference between $\mathrm{N}$ input and $\mathrm{N}$ output terms in a soil system budget) within the Oglio River watershed. Values of the $\mathrm{N}$ surplus were assigned to the centroid of all the over 250 municipalities within the basin and then interpolated by means of the ordinary kriging technique. Calculations were performed with the GIS software SAGA (System for Automated Geoscientific Analyses, version 2.0.5, http://www.saga-gis. org). Data refers to budget calculations performed for the year 2008.

2008). In the Oglio River basin, NUE decreased from 0.43 to 0.39 between 2000 and 2008, reflecting an increased risk of $\mathrm{N}$ runoff and pollution of aquatic ecosystems. Calculated values for the study area lay within the range reported in the literature for maize-based agricultural systems, having generally a NUE < $50 \%$ (Smil, 1999; Cassman et al., 2002).

\subsection{Domestic and industrial contributions to $\mathrm{N}$ pollution}

Nitrogen loads from domestic and industrial sources were calculated in order to evaluate their relevance within the watershed $\mathrm{N}$ budget. The Oglio River basin hosted a population of about 1140000 in 2000 and about 1270000 in 2008 (National Statistics Institution, 2000 and 2008; http://demo. istat.it). Assuming a per capita $\mathrm{N}$ production of $12.5 \mathrm{~g} \mathrm{~d}^{-1}$ (Provini et al., 1998), the $\mathrm{N}$ potential load was $5200 \mathrm{t} \mathrm{N} \mathrm{yr}^{-1}$ in 2000 and $5800 \mathrm{t} \mathrm{N} \mathrm{yr}^{-1}$ in 2008, with an increase of $11 \%$. Domestic $\mathrm{N}$ loads amount to only $\sim 6 \%$ of the total $\mathrm{N}$ input to the Oglio basin in 2008. About $85 \%$ of the total population is connected to the sewage system, meaning that urban wastewater is almost entirely delivered to WWTPs before being discharged into the Oglio River itself or into the secondary drainage system. Based on regional inventory (Lombardy Region, 2006), there are over 210 WWTPs in the Oglio River basin having a total permitted capacity of about 
Table 1. Nitrogen balance in the Oglio River basin computed for the years 2000 and 2008. Data are expressed as tons of nitrogen produced or consumed per year in the whole basin or as kilograms of nitrogen produced or consumed per year per hectare of arable land (AL).

\begin{tabular}{lrrrr}
\hline N balance terms & \multicolumn{2}{c}{2000} & \multicolumn{2}{c}{2008} \\
\hline INPUT & $\mathrm{t} \mathrm{N} \mathrm{yr}^{-1}$ & $\mathrm{~kg} \mathrm{~N} \mathrm{ha}^{-1} \mathrm{AL} \mathrm{yr}^{-1}$ & $\mathrm{t} \mathrm{N} \mathrm{yr}^{-1}$ & $\mathrm{~kg} \mathrm{~N} \mathrm{ha}^{-1} \mathrm{AL} \mathrm{yr}^{-1}$ \\
\hline Livestock manure & 42521 & 187 & 51512 & 232 \\
Synthetic fertilizers & 27640 & 121 & 33564 & 151 \\
Biological fixation & 7975 & 35 & 12182 & 54 \\
Atmospheric deposition & 1800 & 8 & 1800 & 8 \\
Wastewater sludge & - & - & 1057 & 5 \\
\hline Einput & 79936 & 351 & 100115 & 450 \\
\hline OUTPUT & & & & 175 \\
\hline Crop uptake & 34259 & 150 & 38915 & 57 \\
NH & & 125 & 38 \\
Denitrification in soils & 70147 & 31 & 8440 & 270 \\
\hline Eoutput & 51422 & 226 & 60060 & 180 \\
\hline Balance & 28514 & 125 & 40056 & \\
\hline
\end{tabular}

1100000 inhabitants equivalent (IE). Domestic wastewater management is characterized by a multitude of small facilities: about $53 \%$ of the total number of plants have a capacity up to $2000 \mathrm{IE}$ and only $6 \%$ are larger than 10000 IE. The effluents of 9 WWTPs, collecting domestic wastes of only $4 \%$ of the total IE within the watershed, are discharged directly into the Oglio River main course. The remaining facilities are scattered within the catchment and their effluents enter the secondary drainage network.

Our calculation of potential $\mathrm{N}$ load from urban areas is likely a great overestimate of the true $\mathrm{N}$ load discharged into surface water by WWTPs, as we did not consider denitrification occurring in the treatment plants. This is obviously not true because sewage plants with over half $(53 \%)$ of the total permitted capacity in the basin operate denitrification as tertiary treatment (Lombardy Region, 2006), and thus remove a variable fraction of the incoming $\mathrm{N}$ load. As a consequence $\mathrm{N}$ loads released by WWTPs are likely even smaller than $6 \%$ of the other total $\mathrm{N}$ input terms.

Industrial point source $\mathrm{N}$ inputs were estimated considering the number of workers in the different $\mathrm{N}$ polluting industrial sectors and their specific $\mathrm{N}$ production factors (Pagnotta and Barbiero, 2003). Calculations were performed for 2001, the last year for which national census data on industrial activities are available with municipality resolution (National Statistics Institution, 8th Industrial Census 2001; http: //dwcis.istat.it/cis/index.htm). The Oglio River basin hosted in 2001 over 1500000 industrial equivalent inhabitants and the $\mathrm{N}$ load potentially generated was about $7200 \mathrm{t} \mathrm{N} \mathrm{yr}^{-1}$.

\subsection{Diffuse nitrate sources in the Oglio River course}

As nitrate is the dominant $\mathrm{N}$ form in the Oglio River, a tentative budget of this ion was realized in the water course. The aim of this calculation was to confirm outcomes from previous watershed analyses, suggesting large dominance of diffuse nitrogen pollution in this area. We calculated the contribution of diffuse sources of nitrate in the Oglio River by dividing the whole river length into 10 reaches where flow and chemical data were available for both the river and the closing section of each main tributary. In each segment, diffuse sources of nitrate were calculated as the difference between downstream loads and those from upstream plus those discharged from tributaries; results were then integrated the for the whole Oglio River. In this simplified calculation we considered nitrate inputs from tributaries as point sources and we did not consider denitrification nor biological uptake within the river reaches; failure to quantify these processes leads to conservative estimates of diffuse $\mathrm{NO}_{3}^{-}$loads. Outcomes suggested a strong seasonality of the nitrate budget associated with different water flow, but the contribution of point sources to the nitrate load never exceeded $35 \%$ (Fig. 4). As nitrate inputs from tributaries include diffuse loads generated within their sub-basins, the real contribution of point pollution sources in the Oglio River watershed is probably much lower $(<10 \%)$, as suggested by calculations reported in Sects. 4.1 and 4.2. 


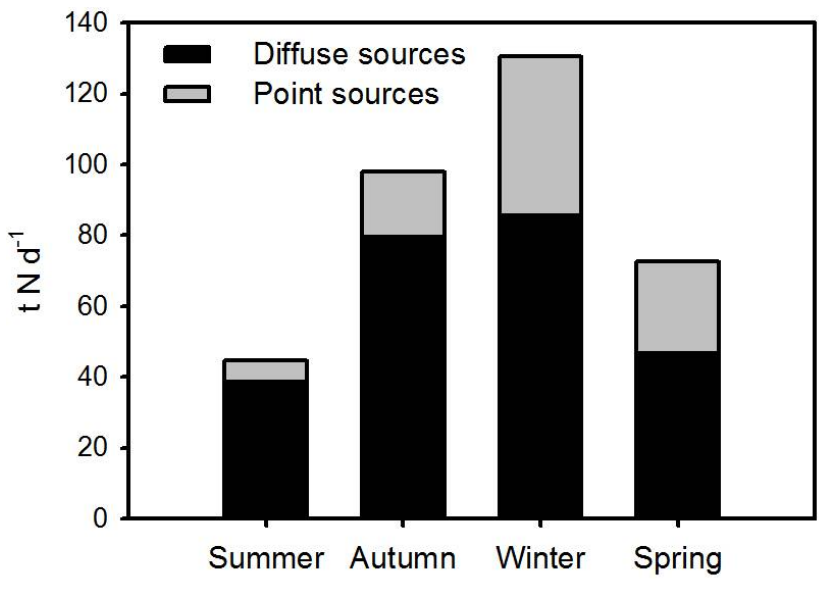

Fig. 4. Contribution of diffuse and point sources to nitrate loads in the Oglio River, calculated in the period 2007-2010.

\section{Export of $\mathrm{N}$ from the basin}

The buffer capacity of a basin against $\mathrm{N}$ pollution of surface water can be evaluated calculating the fraction of the excess nitrogen that is exported from the watershed at its closing section (Caraco et al., 2003). In particular, the higher is this fraction and the lower is the buffer capacity of the system. To this purpose, we estimated from the large dataset of flow and water chemistry data, the annual flux of nitrogen exported via Oglio River discharge. The calculation was performed by multiplying monthly dissolved and particulate nitrogen concentrations $\left(\mathrm{NH}_{4}^{+}, \mathrm{NO}_{2}^{-}, \mathrm{NO}_{3}^{-}\right.$, dissolved organic-DON- and particulate -PN-) by average monthly water flow at the Oglio River origin at the Sarnico dam, and at the river's mouth, and then integrating values to one year. Nitrogen contributions from Lake Iseo were subtracted from outflowing total N loads. Data sources for dissolved and particulate nitrogen concentrations are from the database of the Department of Environmental Sciences of the Parma University for 2007-2010 (Racchetti et al., 2008, 2010) and the database of the Regional Agency for the Environment (ARPA) for 2000 to 2008. Daily flow data were extracted from the database of the Oglio River Consortium (19802010, www.laghi.net/Oglio/).

Calculated total nitrogen export from the watershed approached $13000 \mathrm{t} \mathrm{Nyr}^{-1}$, with $90 \%$ as nitrate. Comparing population (333 inhabitants $\mathrm{km}^{-2}$ ) and $\mathrm{N}$ export $(2950 \mathrm{~kg} \mathrm{~N}$ $\mathrm{NO}_{3}^{-} \mathrm{km}^{-2}$ ) per unit area relative to other impacted watersheds in the world, the Oglio had among the highest of both population density and $\mathrm{N}$ export (Caraco and Cole, 1999; Billen et al., 2011; Soana et al., 2011).

Looking at things from another perspective we can argue that $\mathrm{N}$ export from the basin represents about $34 \%$ of the $\mathrm{N}$ surplus calculated into the watershed for the year 2008, which means that some $26000 \mathrm{tN}$ are somehow retained within the basin, by processes still to be identified. This in turn suggests that there are efficient processes causing a net $\mathrm{N}$ loss or retention in the basin. These mechanisms could permanently remove $\mathrm{N}$ by dissimilative processes (denitrification) or store and/or transport $\mathrm{N}$ in another environmental reservoir (soil, groundwater). Below, we address both of these alternatives.

\section{Denitrification in aquatic habitats}

\subsection{Dissimilative nitrogen loss in wetland habitats: high removal over small surfaces}

Denitrification in lateral shallow habitats is a natural buffering process against nitrogen excess within watersheds. In order to quantify its relevance within the Oglio River we have investigated $\mathrm{N}$ removal via denitrification in a number of perifluvial wetlands (Racchetti et al., 2011). Wetlands are rare in the Oglio River basin, totalling only 200 ha, or $0.05 \%$ of the watershed area. Small, relict wetlands are scattered throughout the watershed. For example, for three study reaches, wetlands - mainly oxbow lakes - occupy less than $5 \%$ of the area within embankment that might be flooded (Fig. 5). There is little potential for formation of new perifluvial areas, because arable land covers more than $60 \%$ of the basin surface and because embankments impede the lateral mobility of the Oglio River. Furthermore, wetland environments are progressively isolated from the main water body by the evolution of the riverine landscape and by eutrophic conditions and rapid infilling.

We characterized benthic fluxes of inorganic nitrogen and rates of denitrification within these isolated and connected environments. During both winter and summer 2007, we collected intact sediment cores from 12 riverine wetlands (marshes, oxbow lakes and ponds) within the Oglio River watershed (Table 2), of which half were hydraulically connected with the river while the remaining were isolated. The cores were incubated in the dark (Dalsgaard et al., 2000), and denitrification rates were measured adding ${ }^{15} \mathrm{NO}_{3}^{-}$to the cores water phase, according to the isotope pairing technique (Nielsen, 1992). This method allows to split total denitrification $\left(D_{\mathrm{TOT}}\right)$ into denitrification of nitrate diffusing to the anoxic sediment from the water column $\left(D_{\mathrm{W}}\right)$ and denitrification of nitrate produced within the sediment due to nitrification $\left(D_{\mathrm{N}}\right)$. Details on analytical methods and calculations are reported in Racchetti et al. (2011).

All sampled environments were eutrophic to hypertrophic, with fluffy and organic sediments (8-33\% organic matter content as loss on ignition), a shallow water column (depth 0.3 to $1.5 \mathrm{~m})$ and small areal extent $(<1$ to $<20 \mathrm{ha})$. Total denitrification rates $\left(D_{\mathrm{TOT}}=D_{\mathrm{W}}+D_{\mathrm{N}}\right)$ were significantly higher in summer than in winter. Rates measured in riverconnected wetlands were up to two orders of magnitude higher than rates measured in isolated ones, likely due to extremely elevated nitrate concentrations in the water column 


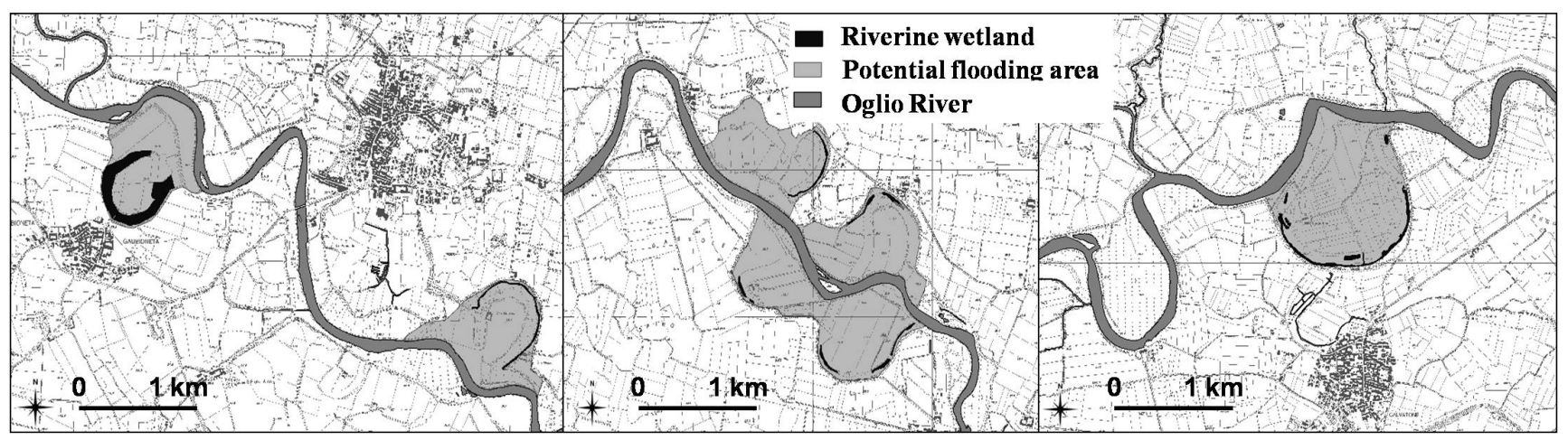

Fig. 5. Examples of relict wetland habitats within the Oglio River watershed. These oxbow lakes have a surface varying between 0.60 and $8.28 \mathrm{ha}$, which is small compared to the area that can be potentially flooded by the Oglio River (from 44.06 to 95.87 ha).

Table 2. In situ nitrate concentration and temperature, ammonium and nitrate plus nitrite fluxes, denitrification rates and denitrification efficiency measured in 12 riverine wetlands during summer and winter 2007. Half of the study sites were connected with $(C)$ and half were isolated $(I)$ from the Oglio River. Total denitrification $\left(D_{\mathrm{TOT}}\right)$ was split into denitrification supported by water column nitrate $\left(D_{\mathrm{W}}\right)$ and denitrification coupled to nitrification in sediments $\left(D_{\mathrm{N}}\right)$. Denitrification efficiency was calculated as the ratio between denitrification rates and inorganic nitrogen effluxes (DIN $+\mathrm{N}_{2}$ ) across the sediment-water interface (Eyre and Ferguson, 2002) and as the ratio between denitrification and the theoretical ammonium production within sediments (A) (Dalsgaard, 2003).

\begin{tabular}{|c|c|c|c|c|c|}
\hline & & \multicolumn{2}{|c|}{ Winter } & \multicolumn{2}{|c|}{ Summer } \\
\hline & & $I$ & $C$ & $I$ & $C$ \\
\hline \multirow{2}{*}{ In situ } & $T\left({ }^{\circ} \mathrm{C}\right)$ & $10.20 \pm 1.02$ & $9.33 \pm 0.61$ & $25.20 \pm 0.20$ & $24.50 \pm 0.56$ \\
\hline & $\mathrm{NO}_{3}^{-}\left(\mathrm{mg} \mathrm{N}^{-1}\right)$ & $0.32 \pm 0.20$ & $9.34 \pm 1.74$ & $0.38 \pm 0.30$ & $8.26 \pm 1.32$ \\
\hline \multirow{2}{*}{ Fluxes } & $\mathrm{NO}_{\mathrm{x}}^{-}\left(\mathrm{mg} \mathrm{N} \mathrm{m}^{-2} \mathrm{~h}^{-1}\right)$ & $-0.43 \pm 1.19$ & $-8.83 \pm 4.40$ & $-1.54 \pm 0.67$ & $-16.53 \pm 11.45$ \\
\hline & $\mathrm{NH}_{4}^{+}\left(\mathrm{mg} \mathrm{N} \mathrm{m}^{-2} \mathrm{~h}^{-1}\right)$ & $2.62 \pm 3.07$ & $-0.25 \pm 0.54$ & $5.15 \pm 1.74$ & $6.29 \pm 6.50$ \\
\hline \multirow{3}{*}{ Denitrification } & $D_{\mathrm{W}}\left(\mathrm{mg} \mathrm{N} \mathrm{m}^{-2} \mathrm{~h}^{-1}\right)$ & $0.69 \pm 0.22$ & $2.07 \pm 0.50$ & $0.90 \pm 0.49$ & $9.12 \pm 3.59$ \\
\hline & $D_{\mathrm{N}}\left(\mathrm{mg} \mathrm{N} \mathrm{m}^{-2} \mathrm{~h}^{-1}\right)$ & $0.04 \pm 0.03$ & $0.46 \pm 0.02$ & $0.24 \pm 0.12$ & $0.58 \pm 0.32$ \\
\hline & $D_{\text {TOT }}\left(\mathrm{mg} \mathrm{N} \mathrm{m}^{-2} \mathrm{~h}^{-1}\right)$ & $0.73 \pm 0.20$ & $2.53 \pm 0.64$ & $1.15 \pm 0.57$ & $9.70 \pm 3.43$ \\
\hline \multirow{2}{*}{$\begin{array}{l}\text { Denitrification } \\
\text { efficiency }\end{array}$} & $D_{\mathrm{TOT}} /\left(D_{\mathrm{TOT}}+\mathrm{DIN}\right)$ & $0.12 \pm 0.03$ & $0.44 \pm 0.17$ & $0.2 \pm 0.07$ & $0.52 \pm 0.10$ \\
\hline & $D_{\mathrm{TOT}} / A$ & $0.58 \pm 0.22$ & $4.43 \pm 0.99$ & $0.48 \pm 0.29$ & $6.75 \pm 1.43$ \\
\hline
\end{tabular}

and to elevated water temperature in summer in the shallowwater systems (Table 2). However, the addition of increasing amounts of ${ }^{15} \mathrm{NO}_{3}^{-}$in the water overlying sediments collected at isolated sites resulted in an immediate stimulation of denitrification rates, suggesting an elevated denitrification potential also for these sediments.

Total denitrification was mostly sustained $(60-100 \%)$ by denitrification of water column nitrate $\left(D_{\mathrm{W}}\right)$, suggesting strong regulation of the benthic denitrification by nitrate availability. The production of nitrate within surface sediments was generally low, due to limited oxygen penetration in organic sediments; as a consequence, rates of coupled nitrification-denitrification $\left(D_{\mathrm{N}}\right)$ had generally a minor importance. Benthic denitrification in hydrologically connected wetlands rapidly removed nitrate from the water column, but mineralization of organic nitrogen and regeneration of ammonium partially balanced nitrogen loss via denitrification at both isolated and connected sites, especially during summer (Table 2).

In order to quantify the maximum potential of wetland areas within the Oglio River Basin to serve as nitrogen sinks via denitrification, we extrapolated the maximum rates measured experimentally at connected sites to all the surface presently occupied by wetlands in Oglio basin. We calculated a maximum potential $\mathrm{N}$ removal in wetlands of $250 \mathrm{t} \mathrm{N} \mathrm{yr}^{-1}$, a very small amount compared to that generated within the basin or exported to the Po River. Overall, N loss via benthic denitrification was a minor fraction $(<1 \%)$ of the basin $\mathrm{N}$ surplus due to limited extent and hydrological connectivity of these environment within the Oglio River. 


\subsection{Nitrogen removal in the Oglio River and in the secondary drainage network}

The relevance of denitrification as natural buffer for excess nitrogen was evaluated also in lotic environments within the Oglio River basin. $\mathrm{N}$ loss in the river course was estimated using a dual isotopic approach $\left(\delta^{15} \mathrm{~N}_{\mathrm{NO}_{3}} \%\right.$ o vs. AIR and $\delta^{18} \mathrm{O}_{\mathrm{NO}_{3}} \%$ vs. V-SMOW). In selected campaigns conducted during 2009 and 2010, water samples were collected from the river its main tributaries and other potential nitrate sources in the watershed for stable isotope analyses of dissolved nitrate (Delconte et al., 2012). Samples were prepared and purified using the ion exchange resin method described by Silva et al. (2000). Nitrate isotopes were determined by IRMS, using a dual inlet Finnigan MAT 250 mass spectrometer. Uncertainties $(1 \sigma)$ are $\pm 0.5 \%$ for $\delta^{15} \mathrm{~N}_{\mathrm{NO}_{3}}$ and $\pm 1 \%$ o for $\delta^{18} \mathrm{O}_{\mathrm{NO}_{3}}$. Denitrification causes the isotopic composition of both $\delta^{15} \mathrm{~N}$ and $\delta^{18} \mathrm{O}$ in nitrate to increase exponentially as nitrate concentration decreases. Isotopic composition increases for both elements in a roughly $2: 1$ ratio, causing data to plot along a slope of about $0.5 \delta^{18} \mathrm{O} / \delta^{15} \mathrm{~N}$ (Fig. 6) (Kendall et al., 2008). Assimilation by phytoplankton also results in an increase in the $\delta^{15} \mathrm{~N}$ and $\delta^{18} \mathrm{O}$ of the residual nitrate, but in this case the ratio of the augment is assumed to be close to $1: 1$ (Granger et al., 2004). Dual isotopic analyses of nitrate are therefore a powerful tool to assess the presence of denitrification or assimilation and quantify their relevance (Deutsch et al., 2009). We report here results from sampling performed in July 2010, during low-flow conditions, although the observed isotopic pattern for the Oglio River water does not show marked seasonal differences (Delconte et al., 2012).

The Oglio River can be divided into three distinct sections based on patterns of nitrate concentration (Fig. 2) and isotopic composition (Fig. 6). In the first $15 \mathrm{~km}$, the isotopic composition indicated an origin from atmospheric deposition or a contribution from synthetic fertilizers. Between 15 and $45 \mathrm{~km}$, the isotopic composition indicated contribution of nitrate derived from anthropogenic organic matter (i.e. ammonification and nitrification of organic nitrogen from manure and/or septic system effluents) to stream nitrate. From $\mathrm{km} 50$ onward, an enrichment in $\delta^{15} \mathrm{~N}$ values was observed, while the $\delta^{18} \mathrm{O}$ values were rather similar to each other, and samples showed no clear distinctive signature of the nitrate origin.

Therefore, in the middle and final reach of the river (grey and black triangles in Fig. 6), a decrease in concentration and an enriched nitrate isotope composition suggest the presence of assimilation or denitrification processes. We believe that nitrogen assimilation by phytoplankton is scarcely relevant in the Oglio River, as suggested by low chlorophyll values in the water (generally below $10 \mu \mathrm{g}^{-1}$, data not shown). Furthermore, decreasing nitrate concentrations and enriched isotopic compositions are a common trend in all seasons, also when primary production is limited by light and temperature (Delconte el al., 2011). On the other hand, while denitrification in the hyporheic zone of the upstream reaches is probably limited by oxic conditions and low organic carbon in the gravel bottom, it is likely to occur downstream, in the riverbed fine sediments. Denitrification may occur as well in soils and groundwater feeding the river. Indeed, in the southern portion of the watershed, denitrification in groundwater is indicated by low nitrate concentrations co-occuring with the presence of dissolved Fe and Mn (ARPA Lombardy, 2009). Unfortunately, the distinction between hyporheic and groundwater denitrification is very difficult to establish, since both processes have similar fractionation factors (Hinkle et al., 2001; Sebilo et al., 2003). If denitrification is occurring, assuming an isotopic difference in $\delta^{15} \mathrm{~N}$ of at most $+4 \%$, and a fractionation factor of 1.020 (Kendall, 1998), it may account for the removal of at most $20 \%$ of the $\mathrm{N}$ load at the Oglio River closing section (Mariotti et al., 1988), corresponding to $\sim 3200 \mathrm{t} \mathrm{yr}^{-1}$.

In the Oglio River basin, direct measurements of denitrification rates in the secondary drainage system, which consists mainly of irrigation channels, are not available. We thus estimated the range of theoretical denitrification rates in this aquatic compartment according to the equation proposed by Christensen et al. (1990) (for more details see Soana et al., 2011). In particular, in order to quantify the maximum potential $\mathrm{N}$ removal via denitrification, we up-scaled the calculated upper rates to the whole surface occupied by the ditch network. The latter was evaluated in about $6250 \mathrm{ha}$, corresponding to a total stream length of over $12500 \mathrm{~km}$, by means of a GIS analysis. The calculated theoretical $\mathrm{N}$ removal is equivalent to $\sim 5500 \mathrm{t} \mathrm{N}$ denitrified during the 5-month period when the system is active for irrigation practices. In addition, assuming the highest denitrification rates reported in the literature (Mander et al., 1997), we estimated that further $\sim 3000 \mathrm{t} \mathrm{N} \mathrm{yr}^{-1}$ of the surplus in the catchment can be removed in vegetated buffer strips adjacent to the secondary drainage network (linear extension of about $9500 \mathrm{~km}$ ).

\section{The relevance of groundwater for $\mathrm{N}$-cycling in the Oglio River watershed}

\subsection{Temporary accumulation and net $\mathrm{N}$ loss in the central and southern portion of the basin}

Denitrification in the Oglio River, in the secondary drainage system and in its riparian area can account for at maximum 3200,5500 and $3000 \mathrm{t} \mathrm{N} \mathrm{yr}^{-1}$, respectively, representing about $45 \%$ of the nitrogen amount which is in excess and not exported out of the Oglio River basin $\left(\sim 26000 \mathrm{t} \mathrm{N} \mathrm{yr}^{-1}\right.$, according to the budget performed for the year 2008). These values are intended as maximal rates of denitrification. The final fate of at least $14300 \mathrm{t} \mathrm{N} \mathrm{yr}^{-1}$ is at present not known, and we speculate whether groundwater can represent a significant site of $\mathrm{N}$ accumulation or loss in this watershed. 


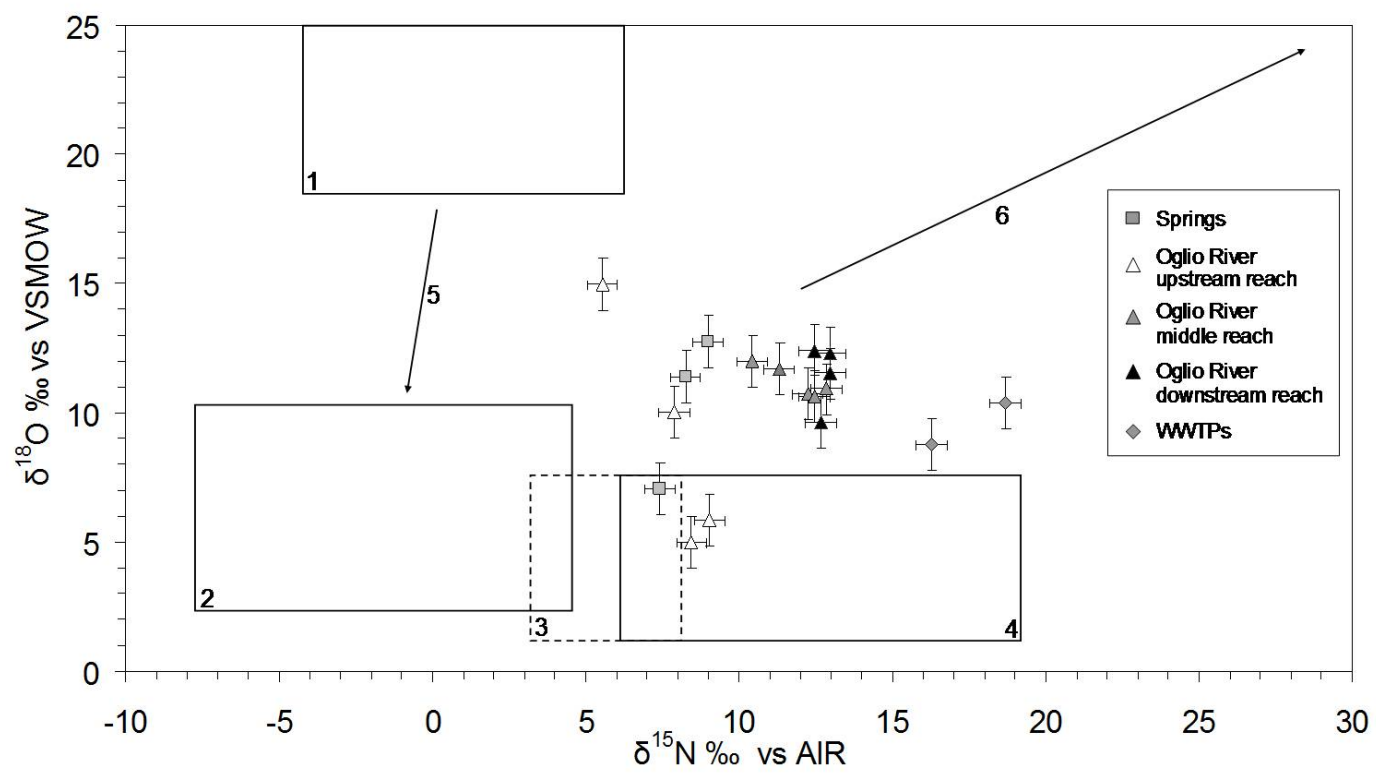

Fig. 6. Isotopic composition of nitrate in water from the Oglio River (white triangles = upstream reach; grey triangles = middle reach; black triangles $=$ downstream reach), springs (squares) and selected WWTPs (diamonds). Compositional fields: 1 - synthetic fertilizers; 2 nitrified synthetic fertilizers; 3 - soil organic matter and contamination from mixed sources; 4 - anthropogenic organic matter (sewage and manure); 5 - evolution during nitrification; 6 - evolution during denitrification. Modified after Kendall (1998), and Clark and Fritz (1997).

In the Oglio River basin, nitrate distribution in groundwater from the shallow unconfined aquifer is not uniform (Fig. 7). Concentrations near or above the threshold for drinking water standards $\left(50 \mathrm{mg} \mathrm{NO}_{3}^{-} \mathrm{l}^{-1}\right.$ or $11.29 \mathrm{mg} \mathrm{N}$ $\mathrm{NO}_{3}^{-} \mathrm{l}^{-1}$ ) are commonly observed in the middle portion of the basin. This area is particularly vulnerable to diffuse contamination, due to the combined effects of coarse-grained soils, flood-based irrigation practices, and widespread maize cultivation, a crop that requires large $\mathrm{N}$ amendments (Figs. 1 and 7). This area also receives a large excess input of animal manure, leading to $\mathrm{N}$ excess (Fig. 3). The downward migration of this $\mathrm{N}$ surplus is also confirmed by nitrate isotope composition, (enriched $\delta^{15} \mathrm{~N}$ and low $\delta^{18} \mathrm{O}$ ), identifying anthropogenic organic matter (i.e. ammonification and nitrification of organic $\mathrm{N}$ from manure and/or septic system effluents) as the pollution source in this area (Sacchi et al., 2011).

We could thus consider groundwater in the central part of the Oglio watershed as an accumulation site for the excess nitrogen, particularly during the irrigation period (MaySeptember). In this area nitrate concentrations have increased in groundwater over the last decade, even in relatively deep wells (>30 m) (ERSAF Lombardy, 2009). This temporal trend is concurrent with the increase in animal manure spreading.

Although these data suggest that groundwater is a $\mathrm{N}$ accumulation site, we have evidences in the Oglio watershed of nitrogen transport from subsurface to surface water network, particularly in the "springs belt" zone between the northern and southern portion of the catchment. This area also corresponds to the reach where the nitrate increases sharply in the Oglio River (Figs. 2 and 7), probably due to nitrate-rich groundwater feeding the river course.

Rapid extraction of large volume of water for irrigation from permeable areas can lead to reduced water residence times in groundwater (Böhlke et al., 2007). This change has multiple implications, such as faster recycling of pollutants (as nitrogen but also herbicides) and reduced transformation by biogeochemical processes (i.e. denitrification).

Confirmation of this accelerated water recycling is obtained by stable isotope analyses of dissolved nitrate. In July 2010, in the upper part of the watershed we collected three groundwater samples characterized by high nitrate concentrations. Their isotopic composition is consistent with other groundwater data from the northern part of the basin (Sacchi et al., 2009, 2011) and is similar to that measured in the Oglio River water in that part of the watershed (Fig. 6). Therefore both concentration trends and nitrate isotope composition suggest the presence of mixing between Oglio River and groundwater. By contrast, in the southern portion of the basin, nitrate is often absent from groundwater, not only due to the low permeability of the unsaturated zone or to comparatively lower $\mathrm{N}$ input. Here, isotopic evidences indicates rapid denitrification occurring within the soil and in groundwater (Sacchi et al., 2011), and this is also confirmed by reducing conditions and the occurrence of $\mathrm{Mn}$ and $\mathrm{Fe}$ in groundwater (ARPA Lombardy, 2009).

We thus conclude that groundwater can be a large potential sink for $\mathrm{N}$, especially in the southern portion of the basin, 


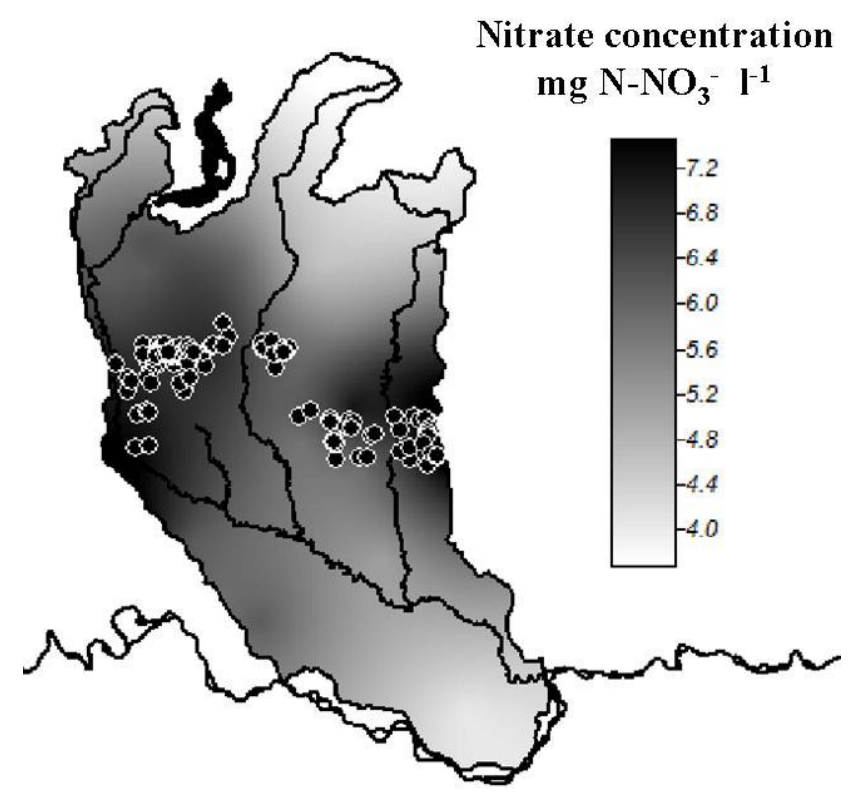

Fig. 7. Mean nitrate concentrations in the surficial aquifer within the Oglio River basin ( $\mathrm{mg} \mathrm{N}_{-} \mathrm{NO}_{3}^{-} \mathrm{1}^{-1}$, data from 2002-2008). Black dots show the location of censused springs within the watershed and highlight the location of the springs belt, which is at the interface between high and middle plain.

where $\mathrm{N}$ is permanently removed via denitrification. On the other hand, in the northern and central part, nitrate accumulates in groundwater and is recycled to the surface, acting as an internal source of pollution.

\subsection{Linking ground and surface water: the spring belt}

Variable water volumes from the unconfined shallow aquifer feed springs or interact with surface water bodies; as a consequence groundwater contaminants and nitrogen in particular can be substantially recycled to the surface. To verify this hypothesis, during 2010 and 2011, water samples were collected from a number of springs and characterized for flow and concentration of dissolved gas and nutrients, in particular $\mathrm{O}_{2}, \mathrm{CO}_{2}, \mathrm{CH}_{4}, \mathrm{~N}_{2} \mathrm{O}, \mathrm{NH}_{4}^{+}, \mathrm{NO}_{2}^{-}$and $\mathrm{NO}_{3}^{-}$(Laini et al., 2011). Water from the springs was generally supersaturated with $\mathrm{N}_{2} \mathrm{O}$ and displayed extremely high $\mathrm{N}-\mathrm{NO}_{3}^{-}$concentrations, up to $20 \mathrm{mg} \mathrm{N}^{-1}$. Overall, within the analyzed watershed, about 50 springs were censused (Fig. 7); each had a relatively low water flow, generally below $501 \mathrm{~s}^{-1}$. They probably represent a small fraction of the deep water that is recycled to the surface, as most of flow occurs not in channels but within the upper soil layers. Subsurface water movements can mobilize the pollutants that are stored in groundwater. On the other hand, groundwater mass balance calculations in the area indicate that the water volume outflowing from springs is up to ten times larger than that feeding the Oglio River, suggesting that the "spring belt" represents one of the main discharge areas of a nitrate-rich shallow aquifer (Lombardy Region, 2006).

We thus speculate that the retention of the nitrate stock in the groundwater of the central and northern portion of the Oglio River watershed is only a temporary buffer as little denitrification and a relevant flux to the surface water is going on. Ultimately, this means that pollution mitigation measures will not lead to immediate results. This observation is in general agreement with the performance evaluation of the Nitrates Directive application, indicating longer recovery time and less performing results for groundwater with respect to surface water (EEA, 2010; Bouraoui and Grizzetti, 2011). This time lag is generally not appreciated by stakeholders.

\section{Summary and conclusions}

In the Oglio River basin, most municipalities have a high population of farmed animals, without sufficient agricultural land for manure spreading. The current legislation specifies upper limits on manure spreading of 170 and $340 \mathrm{~kg} \mathrm{~N} \mathrm{ha}^{-1} \mathrm{yr}^{-1}$, for vulnerable and non-vulnerable soils, respectively. Results from this study indicate much higher amounts resulting in $\mathrm{N}$ surplus exceeding reported limits. They also suggest that the arable land area theoretically necessary to spread manure produced should be 3 times higher than exists. In light of what we have shown any rise of the limits of manure spreading in this vulnerable zone should be carefully considered.

Excess nitrogen can determine multiple environmental impacts. Since both denitrification and nitrification produce nitrous oxide, elevated direct and indirect $\mathrm{N}_{2} \mathrm{O}$ emissions are reported in this area (Laini et al., 2011; Leip et al., 2011). Agricultural and farming activities are the main source of $\mathrm{N}_{2} \mathrm{O}$ and contribute to nearly $2 \%$ of the current greenhouse gas effect (IPCC, 2007). $\mathrm{N}_{2} \mathrm{O}$ is also regarded as the main cause of the destruction of stratospheric ozone in the next future (Ravishankara et al., 2009). Elevated emissions of ammonia to the atmosphere are also expected, with potentially negative consequences as eutrophication, soil acidification, fine particles formation and alteration of the global greenhouse balance (Anderson et al., 2003; Erisman et al., 2007; Leip et al., 2011).

Excessive manure spreading has led to a large excess of bioavailable nitrogen to the Oglio River watershed and to broad-scale diffuse contamination by nitrate. We found elevated concentrations of $\mathrm{N}^{-\mathrm{NO}_{3}^{-}}$in the Oglio River, in most of its tributaries, in all wetlands hydraulically connected with the river, in groundwater and in springs. High concentrations of $\mathrm{N}^{-\mathrm{NO}_{3}^{-}}$in all water compartments is an evident sign of $\mathrm{N}$-saturation in the terrestrial but probably also in the aquatic portions of the watershed (Mullholand et al., 
2008). Available information suggests that the contamination of groundwater is an ongoing process, as nitrate concentrations keep increasing (ERSAF Lombardy, 2009), although the exact timing is presently undetermined.

We demonstrated that wetlands have the potential to remove, per unit area, large amounts of N. Denitrification rates measured at connected sites for example are among the highest reported in the literature, up to $25 \mathrm{mg} \mathrm{N} \mathrm{m}^{-2} \mathrm{~h}^{-1}$ (Seitzinger et al., 2006; Piña-Ochoa and Álvarez-Cobelas, 2006) but they are ineffective sinks due to the small surface. Our results support the importance of restoring lateral interactions between the river and its perifluvial areas, as elevated denitrification potentials were also found at isolated sites.

Nitrate isotope analyses, together with $\mathrm{N}$ mass balance calculations in the Oglio River, also suggest that denitrification in the Oglio River itself is probably a minor $\mathrm{N}$ sink. The lateral interactions with the surronding areas are in fact extremely limited in time and in space due to the regulation of water flow and the presence of banks for most of its course. The secondary drainage network is capillary extended in this watershed and accounts for 100 times the length of the river, with proportionally more interfaces for microbial processes to occur. The secondary drainage network may be an important sink for bioavailable nitrogen owing to its hydrological connections with terrestrial systems, high rates of biological activity, and streambed sediment environments that favour microbial denitrification. Still, our estimates suggest that nitrogen removal via denitrification in irrigation channels is at maximum $45 \%$ of the missing nitrogen amount.

An important $\mathrm{N}$-sink function within the watershed is likely contributed by processes that result in net $\mathrm{N}$ accumulation and not in a net N-permanent loss. Such accumulation can result in nitrate contamination of groundwater, but also in organic $\mathrm{N}$ enrichment within arable lands or particulate $\mathrm{N}$ burial in aquatic environments, the latter two not considered in the present study. Nitrogen accumulation in groundwater can be a large potential sink for $\mathrm{N}$, but it could be temporary as stored $\mathrm{N}$ could be recycled to the surface and act as an internal source of pollution, with strong analogies with organic sediments in eutrophic lakes (Puckett et al., 2011). Even if allochtonous sources of pollution are controlled, lakes can remain eutrophic for many years as nutrient recycling sustains primary productivity.

Detailed investigation by hydrogeologists is needed, in order to clarify the path of groundwater and to date the nitrogen that is recycled by springs. This will allow for an estimation of the time required by groundwater to recover from nitrate pollution if $\mathrm{N}$ loads are significantly reduced in the future.

Acknowledgements. This study is a contribution to the PRIN 2008 project "Nitrogen loads in the Po river basin: biogeochemical processes, tranformations and effects in lowland reaches, transitional and coastal waters", funded by the Italian Ministry of University and Research. Stable isotope data were produced in the frame of a research project supported by CNR-IGG and Lombardy Region, Department of Agriculture. The authors wish to acknowledge
Ing. M. Buizza, Oglio River Consortium Director, and the Regional Agency for the Environmental Protection of Lombardy for data provision. E. Racchetti was supported by the FLA (Lombardy Foundation for the Environment). The authors wish to thank two anonymous reviewers for their helpful suggestions and Christy Goodale for her expert comments and discussion on early version of this manuscript.

Edited by: G. Billen

\section{References}

A.P.H.A., A.W.W.A., W.P.C.F. (Eds.): Standard methods for the examination of water and wastewater, Am. Publ. Health Ass., Washington, 1981.

Agricultural Information System of Lombardy Region, available at: www.siarl.regione.lombardia.it, last access: 10 March 2011, 2008.

Anderson, N. J., Strader, R., and Davidson, C.: Airborne reduced nitrogen: ammonia emissions from agriculture and other sources, Environ. Int., 29, 277-286, 2003.

ARPA Lombardy (Environmental Protection Agency) (Eds.): Environmental signals, Report on environmental state in Lombardy 2008-2009, Milano, Italy, 2009 (in Italian).

Asman, W. A. H.: Factors influencing local dry deposition of gases with special reference to ammonia, Atmos. Environ., 32, 415421, 1998.

Balestrini, R., Arese, C., Delconte, C. A., Lotti, A., and Salerno, F.: Nitrogen removal in subsurface water by narrow buffer strips in the intensive farming landscape of the Po River watershed, Italy, Ecol. Eng., 37, 148-157, 2011.

Billen, G., Silvestre, M., Grizzetti, B., Leip, A., Garnier, J., Voss, M., Howarth, R., Bouraoui, F., Darracq, A., Behrendt, H., Lepisto, A., Kortelainen, P., Johnes, P., Curtis, C., Humborg, C., Smedberg, E., Kaste O., Ganeshram, R., Beusen A., and Lancelot, C.: Nitrogen flows from European regional watersheds to coastal marine waters, in: The European nitrogen assessment, edited by: Sutton, M. and Howard, C., Cambridge, MA, Cambridge University Press, 2011.

Böhlke, J. K, Verstraeten, I. M., and Kraemer, T. K.: Effects of surface-water irrigation on sources, fluxes and residence times of water, nitrate, and uranium in an alluvial aquifer, Appl. Geochem., 22, 152-174, 2007.

Bouraoui, F. and Grizzetti, B.: Long term change of nutrient concentrations of rivers discharging in European seas, Sci. Total Environ., 409, 4899-4916, 2011.

Brenna, S., D'Alessio, M., and Solaro, S. (Eds.): Soil map of Lombardy, scale 1:250,000, S.E.L.C.A., Firenze, 2004.

Bussink, D. W. and Oenema, O.: Ammonia volatilization from dairy farming systems in temperate areas: a review, Nutr. Cycl. Agroecosys., 51, 19-33, 1998.

Caraco, N. F. and Cole, J. J.: Human Impact on Nitrate Export: an Analysis Using Major World Rivers, Ambio, 28, 167-170, 1999.

Caraco, N. F., Cole, J. J., Likens, G. E., Lovett, G. M., and Weathers, K. C.: Variation in $\mathrm{NO}_{3}$ export from flowing waters of vastly different sizes: does one model fit all?, Ecosystems, 6, 344-352, 2003.

Carcano, C. and Piccin, A. (Eds.): Geology of Po plain aquifers, Lombardy Region, ENI-Agip division, S.E.L.C.A., Firenze, 
2002.

Cassman, K. G., Dobermann, A., and Walters, D. T.: Agroecosystems, nitrogen-use efficiency, and nitrogen management, Ambio, 31, 132-140, 2002.

Christensen, P. B., Nielsen, L. P., Sørensen, J., and Revsbech, N. P.: Denitrification in Nitrate-rich Streams: Diurnal and Seasonal Variations Related to Benthic Oxygen Metabolism, Limnol. Oceanogr., 35, 640-651, 1990.

Cinnirella, S., Buttafuoco, G., and Pirrone, N.: Stochastic analysis to assess the spatial distribution of groundwater nitrate concentrations in the Po catchment (Italy), Environ. Pollut., 133, 569580, 2005.

Clark, I. and Fritz, P. (Eds.): Environmental Isotopes in Hydrogeology, Lewis Publishers, Boca Raton, 328 pp., 1997.

Cóndor, R. D., Di Cristofaro, E., and De Lauretis, R.: Agriculture, national greenhouse gas emission inventory in Italy, Institute for Environmental Protection and Research, 2008 (in Italian).

Dalsgaard, T.: Benthic primary production and nutrient cycling in sediments with benthic microalgae and transient accumulation of macroalgae, Limnol. Oceanogr., 48, 2138-2150, 2003.

Dalsgaard, T., Nielsen, L. P., Brotas, V., Viaroli, P., Underwood, G. J. C., Nedwell, D. B., Sundbäck, K., Rysgaard, S., Miles, A., Bartoli, M., Dong, L., Thornton, D. C. O., Ottosen, L. D. M., Castaldelli, G., and Risgaard-Petersen, N. (Eds.): Protocol handbook for NICE-nitrogen cycling in estuaries: a project under the EU research programme, Marine Science and Technology (MAST III), National Environmental Research Institute, Silkeborg, 2000.

Davidson, E. A.: Contribution of manure and fertilizer nitrogen to increasing atmospheric nitrous oxide since 1860, Nat. Geosci., 2, 659-662, 2009.

Delconte, C. A., Sacchi, E., Allais, E., and Racchetti, E.: Evaluation of nitrate sources and transformation in the Oglio River watershed, Proceedings International Symposium on Isotopes in Hydrology, Marine Ecosystems, and Climate Change Studies, Oceanographic Museum, Monaco, Principality of Monaco, 27 March-1 April 2011, IAEA-CN-186-073, in press, 2012.

Deutsch, B., Voss, M., and Fischer, H.: Nitrogen transformation processes in the Elbe River: distinguishing between assimilation and denitrification by means of stable isotope ratios in nitrate, Aquat. Sci., 71, 228-237, 2009.

EEA European Environment Agency: Nutrients in freshwater (CSI 020) - Assessment, available at: http://www.eea. europa.eu/data-and-maps/indicators/nutrients-in-freshwater/ nutrients-in-freshwater-assessment-published-4, last access: 1 September 2011, 2010.

Erisman, J. W., Bleeker, A., Galloway, J., and Sutton, M. S.: Reduced nitrogen in ecology and the environment, Environ. Pollut., 150, 140-149, 2007.

ERSAF Lombardy (Regional Agency for Development of Agriculture and Forestry) (Eds.): Report on Nitrates Directive implementation in Lombardy, Milan, Italy, 2009 (in Italian).

Eyre, B. D. and Ferguson, A. J. P.: Comparison of carbon production and decomposition, benthic nutrient fluxes and denitrification in seagrass, phytoplankton, benthic microalgae and macroalgae dominated warm-temperate Australian lagoons, Mar. Ecol.Prog. Ser., 229, 43-59, 2002.

Franco, P. and Michelato, A: Northern Adriatic Sea: oceanography of the basin proper and of the western coastal zone, in: Science of the Total Environment supplement, Marine Coastal Eutrophication, edited by: Vollenweider, R. A., Marchetti, R., and Viviani, R., Elsevier, Amsterdam, 35-62, 1992.

Galloway, J. N., Townsend, A. R., Erisman, J. W., Bekunda, M., Cai, Z., Freney, J. R., Martinelli, L. A., Seitzinger, S. P., and Sutton, M. A.: Transformation of the nitrogen cycle: Recent trends, questions, and potential solutions, Science, 320, 889-892, 2008.

Granger, J., Sigman, D. M., Needoba, J. A., and Harrison, P. J.: Coupled nitrogen and oxygen isotope fractionation of nitrate during assimilation by cultures of marine phytoplankton, Limnol. Oceanogr., 49, 1763-1773, 2004.

Hinkle, S. R., Duff, J. H., Triska, F. J., Laenen, A., Gates, E. B., Bencala K. E., Wentz, D. A., and Silva, S. R.: Linking hyporheic flow and nitrogen cycling near the Willamette River - A large river in Oregon, USA, J. Hydrol., 244, 157-180, 2001.

Howarth, R. W., Billen, G., Swaney, D., Townsend, A., Jaworski, N., Lajtha, K., Downing, J. A., Elmgren, R., Caraco, N., Jordan, T., Berendse, F., Freney, J., Kudeyarov, V., Murdoch, P., and Zhu, Z. L.: Regional nitrogen budgets and riverine N \& P fluxes for the drainages to the North Atlantic Ocean: Natural and human influences, Biogeochemistry, 35, 75-139, 1996.

Howarth, R. W., Swaney, D., Billen, G., Garnier, J., Hong, B., Humborg, C., Johnes, P., Mörth, C. M., and Marino, R.: Nitrogen fluxes from the landscape are controlled by net anthropogenic nitrogen inputs and by climate, Front. Ecol. Environ., doi:10.1890/100178, 2011.

Kendall, C.: Tracing nitrogen sources and cycling in catchments, in: Isotope tracers in catchment hydrology, edited by: Kendall, C. and McDonnell, J. J., Elsevier, Amsterdam, 519-576, 1998.

Kendall, C., Elliott, E. M., and Wankel, S. D.: Tracing anthropogenic inputs $f$ nitrogen to ecosystems, in: Stable Isotopes in Ecology and Environmental Science, edited by: Michener, R. and Lajtha, K., Blackwell Publishing, Oxford UK, 375-449, 2008.

IPCC (Intergovernmental Panel on Climate Change): Climate change 2007: Synthesis Report. Contribution of Working Groups I, II and III to the Fourth Assessment Report of the Intergovernmental Panel on Climate Change, Core Writing Team, edited by: Pachauri, R. K. and Reisinger, A., IPCC, Geneva, Switzerland, 104 pp., 2007.

Laini, A., Bartoli, M., Castaldi, S., Viaroli, P., Capri, E., and Trevisan, M.: Greenhouse gas $\left(\mathrm{CO}_{2}, \mathrm{CH}_{4}\right.$ and $\left.\mathrm{N}_{2} \mathrm{O}\right)$ in lowland springs within an agricultural impacted watershed (Po River Plain, Northern Italy), Chem. Ecol., 27, 177-187, 2011.

Leip, A., Achermann, B., Billen, G., Bleeker, A., Bouwman, A. F., de Vries, W., Dragosits, U., Döring, U., Fernall, D., Geupel, M., Herolstab, J., Johnes, P., Le Gall, A. C., Monni, S., Nevečeřal, R., Orlandini, L., Prud'homme, M., Reuter, H. I., Simpson, D., Seufert, G., Spranger, T., Sutton, M. A., van Aardenne, J., Voß, M., and Winiwarter, W.: Integrating nitrogen fluxes at the European scale, in: The European nitrogen assessment, edited by: Sutton, M. and Howard, C., Cambridge, MA, Cambridge University Press, 2011.

Liu, C., Watanabe, M., and Wang, Q.: Changes in nitrogen budgets and nitrogen use efficiency in the agroecosystems of the Changjiang River basin between 1980 and 2000, Nutr. Cycl. Agroecosys., 80, 19-37, 2008.

Lombardy Region: Water Protection Plan, Attachment Three Quantitative status classification of plain aquifers, available 
at: http://www.ors.regione.lombardia.it/resources/pagina/ N12032ced450401d4ce6/N12032ced450401d4ce6/allegato_3. pdf, last access: 13 January 2010, 2006.

Mander, U., Kuusemets, V., Lohmus, K., and Mauring, T.: Efficiency and dimensioning of riparian buffer zones in agricultural catchments, Ecol. Eng., 8, 299-306, 1997.

Mariotti, A., Landreau, A., and Simon, B.: ${ }^{15} \mathrm{~N}$ isotope biogeochemistry and natural denitrification process in groundwater: Application to the chalk aquifer of northern France, Geochim. Cosmochim. Ac., 52, 1869-1878, 1988.

Mulholland, P. J., Helton, A. M., Poole, G. C., Hall, R. O., Hamilton, S. K., Peterson, B. J., Tank, J. L., Ashkenas, L. R., Cooper, L. W., Dahm, C. N., Dodds, W. K., Findlay, S. E. G., Gregory, S. V., Grimm, N. B., Johnson, S. L., McDowell, W. H., Meyer, J. L., Valett, H. M., Webster, J. R., Arango, G. P., Beaulieu, J. J., Bernot, M. J., Burgin, A. J., Crenshaw, C. L., Johnson, L. T., Niederlehner, B. R., O’Brien, J. M., Potter, J. D., Sheibley, R. W., Sobota, D. J., and Thomas, S. M.: Stream denitrification across biomes and its response to anthropogenic nitrate loading, Nature, 452, 202-205, 2008.

National Statistics Institution: 5th Agricultural Census, available at: http://censagr.istat.it/dati.htm, last access: 10 March 2011, 2000.

National Statistics Institution: 8th Industrial Census, available at: http://dwcis.istat.it/cis/index.htm, last access: 10 March 2011, 2001.

National Statistics Institution: demographic statistics for the years 2000 and 2008, available at: http://demo.istat.it, last access: 10 March 2011, 2000 and 2008.

Nielsen, L. P.: Denitrification in sediment determined from nitrogen isotope pairing, FEMS (Federation of European Microbiological Societies), Microb. Ecol., 86, 357-362, 1992.

Oenema, O., Kros, H., and De Vries, W.: Approaches and Uncertainties in Nutrient Budgets: Implications for Nutrient Management and Environmental Policies, Eur. J. Agron., 20, 3-16, 2003.

Oglio River Consortium: Daily flow data of the Oglio River, available at: http://www.laghi.net/Oglio/, last access: 10 June 2011 (in Italian).

Pagnotta, R. and Barbiero, G.: Assessment of pollutants load in the coastal environment, Annali ISS, 39, 3-10, 2003 (in Italian).

Piña-Ochoa, E. and Álvarez-Cobelas, M.: Denitrification in Aquatic Environments: a Cross-system Analysis, Biogeochemistry, 81, 111-130, 2006.

Provini, A., Galassi, S., and Marchetti, R. (Eds.): Applied Ecology, Città Studi Edizioni, Torino, 1216, 1998 (in Italian).

Puckett, L. J.: Identifying the major sources of nutrient water pollution, Environ. Sci. Technol., 29, 408-414, 1995.

Puckett, L. J., Tesoriero, A. J., and Dubrovsky, N. M.: Nitrogen contamination of surficial aquifers - a growing legacy, Environ. Sci. Technol., 45, 839-844, 2011.

Racchetti, E., Soana, E., Longhi, D., Bartoli, M., and Viaroli, P.: Definition of an Action Plan for the lower Oglio River restoration, Department of Environmental Sciences of Parma University and Oglio Sud Park, Parma, Italy, 2008 (in Italian).

Racchetti, E., Bartoli, M., Soana, E., Bolpagni, R., Laini, A., Longhi, D., Mancini, M., Dalmiglio, A., Buizza, M., and Viaroli, P: Towards the definition of the minimum vital flow for the lower Oglio River, Department of Environmental Sciences of Parma University and the Oglio River Consortium, Brescia, Italy, 2010 (in Italian).
Racchetti, E., Bartoli, M., Soana, E., Longhi, D., Christian, R. R., Pinardi, M., and Viaroli, P.: Influence of Hydrological connectivity of riverine wetlands on nitrogen removal via denitrification, Biogeochemistry, 103, 335-354, 2011.

Ravishankara, A. R., Daniel, J. S., and Portmann, R. W.: Nitrous oxide $\left(\mathrm{N}_{2} \mathrm{O}\right)$ : the dominant ozone-depleting substance emitted in the 21st century, Science, 326, 123-125, 2009.

Rotz, C. A.: Management to reduce nitrogen losses in animal production, J. Anim. Sci., 82, 119-137, 2004.

Sacchi, E., Pilla, G., Guffanti, S., Allais, E., and Delconte, C.: Stable isotopes of dissolved nitrate as indicators of the origin and mechanisms of transport to/removal from groundwater: results from the western Po plain. Proceedings of the 16th Nitrogen Workshop, Turin, Italy, 28 June-1 July 2009, 495-496, 2009.

Sacchi, E., Delconte, C. A., Pennisi, M., and Allais, E.: Stable isotopes of dissolved nitrate and boron as indicators of the origin and fate of nitrate contamination in groundwater: results from the western Po Plain (Northern Italy), Proceedings International Symposium on Isotopes in Hydrology, Marine Ecosystems, and Climate Change Studies, Oceanographic Museum, Monaco, 27 March-1 April 2011, IAEA-CN-186-070, 2011.

Sebilo, M., Billen, G., Grably, M., and Mariotti, A.: Isotopic composition of nitrate-nitrogen as a marker of riparian and benthic denitrification at the scale of the whole Seine River system, Biogeochemistry, 63, 35-51, 2003.

Seitzinger, S., Harrison, J. A., Bohlke, J. K., Bouwman A. F., Lowrance, R., Peterson, B., Tobias, C., and Van Drecht, G.: Denitrification Across Landscapes and Waterscapes: A Synthesis, Ecol. Appl., 16, 2064-2090, 2006.

Silva, S. R., Kendall, C., Wilkison, D. H., Ziegler, A. C., Chang, C. C. Y., and Avanzino, R. J.: A new method for collection of nitrate from fresh water and the analysis of nitrogen and oxygen isotope ratios, J. Hydrol., 228, 22-36, 2000.

Smil, V.: Nitrogen in crop production: an account of global flows, Global Biogeochem. Cy., 13, 647-662, 1999.

Soana, E., Racchetti, E., Laini, A., Bartoli, M., and Viaroli, P.: Soil budget, net export and potential sinks of nitrogen in the lower Oglio River watershed (northern Italy), Clean-Soil Air Water, 39, 956-965, 2011.

van Breemen, N., Boyer, E. W., Goodale, C. L., Jaworski, N. A., Paustian, K., Seitzinger, S. P., Lajtha, K., Mayer, B., Van Dam, D., Howarth, R. W., Nadelhoffer, K. J., Eve, M., and Billen, G.: Where did all the nitrogen go? Fate of nitrogen inputs to large watersheds in the northeastern U.S.A., Biogeochemistry, 57-58, 267-293, 2002.

Vitousek, P. M., Aber, J. D., Howarth, R. W., Likens, G. E., Matson, P. A., Schindler, D. W., Schlesinger, W. H., and Tilman, D. G.: Alteration of the global nitrogen cycle: sources and consequences, Ecol. Appl., 7, 737-750, 1997.

Ward, M. H., deKok, T. M., Levallois, P., Brender, J., Gulis, G., Nolan, B. T., and Van Derslice, J.: Workgroup report: Drinking water nitrate and health-Recent findings and research needs, Environ. Health Persp., 113, 1607-1614, 2005.

Zoppini, A., Pettine, M., Totti, C., Puddu, A., Artegiani, A., and Pagnotta, R.: Nutrients, standing crop, and primary production in western coastal waters of Adriatic Sea, Estuar. Coast. Shelf S., 41, 493-513, 1995. 